This work is licensed under a Creative Commons Attribution License (CC BY 4.0).

Research article

\title{
Checklist and a new species of Lippia (Verbenaceae) from the Diamantina Plateau, Minas Gerais, Brazil
}

\author{
Pedro Henrique CARDOSO ${ }^{1, *}$, Luiz MENINI NETO ${ }^{2}$, \\ Marcelo TROVÓ $^{3}$ \& Fátima Regina Gonçalves SALIMENA ${ }^{4}$ \\ Quinta da Boa Vista, CEP 20940-040, Rio de Janeiro, RJ, Brazil. \\ Herbário Leopoldo Krieger, CEP 36036-900, Juiz de Fora, MG, Brazil. \\ Av. Carlos Chagas Filho 373, CEP 21941-590, Rio de Janeiro, RJ, Brazil.

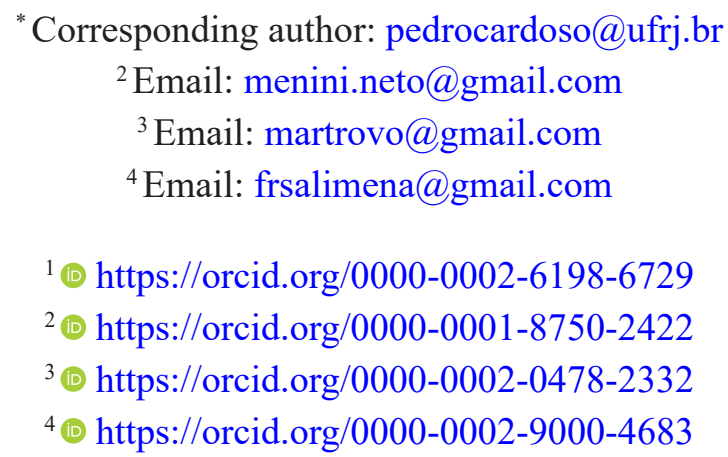

${ }^{1}$ Universidade Federal do Rio de Janeiro, Museu Nacional, Departamento de Botânica,

${ }^{2,4}$ Universidade Federal de Juiz de Fora, Instituto de Ciências Biológicas, Departamento de Botânica,

${ }^{3}$ Universidade Federal do Rio de Janeiro, Instituto de Biologia, Departamento de Botânica,

\begin{abstract}
The Diamantina Plateau is located in the central region of the Espinhaço Range, in the State of Minas Gerais, which is dominated by campo rupestre formations. We describe a new species of Lippia L., endemic to the Diamantina Plateau, and provide an annotated checklist and identification key for the 17 species of the genus occurring in the area. Lippia raoniana P.H.Cardoso \& Salimena sp. nov. is mainly distinguished by its ovate leaves with adaxial and abaxial surfaces densely covered by sessile glandular trichomes, and drupaceous fruits with two pyrenes. It is known only from two populations, and thus can be provisionally considered as Critically Endangered. Details on the species' ecology, as well as a comparison with morphologically similar species, a distribution map, and field photographs, are provided. In this work, we also present pictures of the 17 species in their habitats, and we hope that these illustrations will help in the identification and conservation of these taxa.
\end{abstract}

Keywords. Endangered species, endemism, Espinhaço Range, Lamiales, Lantaneae.

Cardoso P.H., Menini Neto L., Trovó M. \& Salimena F.R.G. 2021. Checklist and a new species of Lippia (Verbenaceae) from the Diamantina Plateau, Minas Gerais, Brazil. European Journal of Taxonomy 733: 42-55. https://doi.org/10.5852/ejt.2021.733.1219 


\section{Introduction}

The flowering plant genus Lippia L. is a member of the tribe Lantaneae Endl. in the vervain family (Verbenaceae J.St.-Hil.). It contains approximately 120 species of perennial herbs, shrubs and subshrubs, often aromatic, native to tropical regions of the Americas and Africa (Atkins 2004; Marx et al. 2010). The genus is difficult to distinguish from Lantana L., given that the two genera are segregated by the fruit morphology only. Chamisso (1832) characterized Lippia by the presence of schizocarpic fruits bearing two cluses or drupaceous fruits with two pyrenes. Schauer (1847) assigned species with drupes to Lantana and species with schizocarps to Lippia. Finally, Silva \& Salimena (2002) redelimited Lantana and reestablished the circumscription proposed by Chamisso (1832) to include only species with monopyrenous drupes.

The relationship between Lippia and Lantana is subject to a continuous taxonomic discussion and several delimitations have previously been proposed (Chamisso 1832; Schauer 1847; Troncoso 1974; Silva 1999; Sanders 2001; Silva \& Salimena 2002; Atkins 2004). Phylogenetic analyses indicate that neither genus is monophyletic and both must be recircumscribed (Lu-Irving \& Olmstead 2013), but an updated classification is yet to be published.

The highest species richness in Lippia is concentrated in Brazil, with ca 90 species (Salimena \& Cardoso 2020; Cardoso et al. 2019b, 2019c, 2020b). The majority of these occur in the Espinhaço Range (Salimena et al. 2009), which extends for over $1000 \mathrm{~km}$, north to south, from the State of Bahia to the State of Minas Gerais. The region is characterized primarily by its quartzite rocky outcrops (i.e., campos rupestres), with elevations reaching 2000 m (Almeida-Abreu 1995; Giulietti et al. 1997; Gontijo 2008).

The Diamantina Plateau, located in the mid-southern region of the Espinhaço Range, Minas Gerais State, is bounded north from the Serra do Cipó and south from Grão Mogol (Gonçalves et al. 2017). It represents the highest plane surface (King 1956), and the watershed between the São Francisco and Jequitinhonha River basins along the N/S axis. The Diamantina Plateau is considered one of the most important centres of plant diversity and endemism in the Espinhaço Range (Giulietti et al. 1997; Echternacht et al. 2011). It is included in the Espinhaço Range Biosphere Reserve (UNESCO 2005), situated between the Cerrado and the Atlantic Forest domains, two global hotspots of biodiversity and conservation priorities (Myers et al. 2000).

Ongoing taxonomic studies on Verbenaceae for the "Flora do Brasil 2020" project (http://floradobrasil.jbrj.gov.br/), with extensive analyses of herbarium specimens and fieldwork, allowed the recognition of a new species of Lippia. This new species appears endemic to the Diamantina Plateau in the Espinhaço Range, State of Minas Gerais, and is described and illustrated in the present study. Furthermore, we provide an annotated checklist, identification key, and pictures of the species of Lippia in the Diamantina Plateau, with the aim of increasing our knowledge of the local flora, which is essential for conservation purposes.

\section{Material and methods}

Collections of the new species deposited in the herbaria CESJ, ICN, RB and SPF (acronyms of herbaria follow Index Herbariorum (Thiers, continuously updated)) were examined and field expeditions were conducted to observe individuals in their natural habitat. Morphological terminology follows Radford et al. (1974), Harris \& Harris (2003), and Gonçalves \& Lorenzi (2007). Conservation status is in accordance with the IUCN (2019) criteria; the area of occupancy (AOO) is based on $2 \times 2 \mathrm{~km}$ grids. The geographical distribution map was prepared using QGIS ver. 3.8 (QGIS Development Team 2018). An identification key to the species of Lippia from the Diamantina Plateau was elaborated by consulting the type specimen images available at Global Plants on JSTOR (https://plants.jstor.org/)and collections 
available from BR, CESJ, F, G, HAL, K, M, MBML, P, R, RB, SP, SPF, VIC and W as well as several herbaria at Herbário Virtual Reflora (reflora.jbrj.gov.br/). Species' distribution records were obtained from the herbaria consulted and followed the delimitation of the Diamantina Plateau proposed by Gonçalves et al. (2017). This delimitation differs from the one proposed by Rapini et al. (2002) since it excludes the Serra do Cabral. This location is separated from the remaining Espinhaço Range by the geological depression, which is drained by the Jequitaí and Curimataí Rivers (Saadi 1995).

\title{
Results
}

\section{Taxonomic treatment}

\author{
Class Magnoliopsida Brongn. \\ Order Lamiales Bromhead \\ Family Verbenaceae J.St.-Hil. \\ Genus Lippia L.
}

Lippia raoniana P.H.Cardoso \& Salimena sp. nov. urn:lsid:ipni.org:names:77214745-1

Figs 1, 4 B-C

\section{Diagnosis}

The new species is similar to Lippia spiraeastrum (Mart. \& Schauer) T.R.S.Silva, but differs by ovate leaves (vs oblong or oblong-elliptic), slightly discolorous (vs strongly discolorous), matte adaxial surface (vs shiny), glandular abaxial surface (vs tomentose-glandular), shorter peduncle (0.8-1.3 vs $3.2-10.5 \mathrm{~cm}$ long) and slender (vs thick), ovate bracts (vs lanceolate).

\section{Etymology}

The specific epithet is in homage to Raoni Metuktire, an important indigenous leader of Brazil, internationally known as a symbol of environmental preservation. Raoni is dedicated to the fight for the rights of native indigenous people and conservation of the tropical forest, mainly Amazonia. His legacy is a symbol of the daily struggle for Brazilian biodiversity, constantly threatened.

\section{Material examined}

\section{Type}

BRAZIL - Minas Gerais • Serro, "próximo ao Km 1 do distrito de Milho Verde" [near to Km 1 of the Milho Verde district];18²7'35.1" S, 4329'24.4" W; 13 Feb. 2020; fl/fr; F.R.G. Salimena \& P.H. Nobre 4057; holotype: CESJ; isotypes: HUEFS, RB, SPF.

\section{Paratypes}

BRAZIL - Minas Gerais • Felício dos Santos, "APA Municipal Felício” [Municipal Environmental Protection Area Felício]; 10 Jun. 2006; fl/fr; F.R.G. Salimena et al. 1382; CESJ - Serro, "estrada Diamantina para o distrito de Milho Verde" [road from Diamantina to the Milho Verde district]; 16 Nov. 2010; fl/fr; V. Thode, P. Lu-Irving, N. Mota, M. Toledo 386; CESJ, ICN.

\section{Description}

Shrub $1.5 \mathrm{~m}$ tall, aromatic, branched, branches erect, tetragonal, sulcate, glabrescent to strigose, with sessile glandular trichomes, nodes conspicuous. Leaves decussate, patent, congested at the stem apices, petioles 2.2-6 mm long, cylindrical, strigose, with abundant sessile glandular trichomes; blades 1.5-3 $\times$ $0.8-1.5 \mathrm{~cm}$, chartaceous, ovate, slightly discolorous, apex acute to obtuse, base cuneate, decurrent into the petiole, margin basally entire, crenate to serrate toward the apex, ciliate, slightly revolute, adaxial 
surface matte, sparsely strigose, densely covered by sessile glandular trichomes, abaxial surface densely covered by sessile glandular trichomes, strigose along the veins. Inflorescence one per axil, $0.5-1 \mathrm{~cm}$ long, capituliform, hemispherical, rachis not elongated in the infructescence, peduncle $0.8-1.3 \mathrm{~cm}$ long, cylindrical, slender, strigose, with abundant sessile glandular trichomes; bracts 3-5 mm long, green, spirally arranged, ovate, apex acute to obtuse, margin ciliate, adaxial surface strigose, covered by sessile
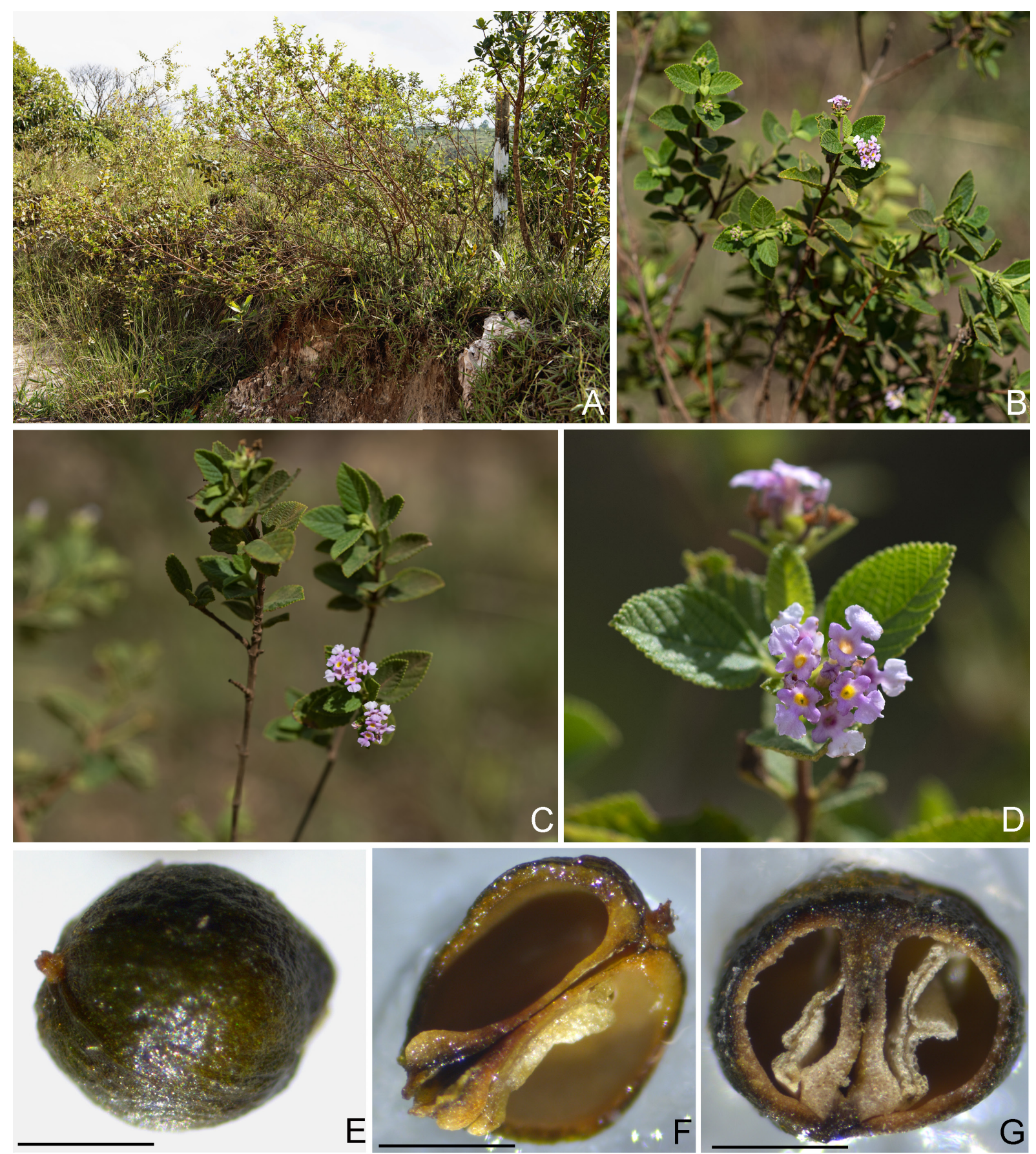

Fig. 1. Lippia raoniana P.H.Cardoso \& Salimena sp. nov. A. Habit. B-C. Branch with inflorescence. D. Inflorescence frontal view. E-G. Drupaceous fruit. E. Overview. F. Longitudinal section showing two pyrenes. G. Cross section showing two pyrenes and seeds. Scale bars: $E-G=1 \mathrm{~mm}$. Photos: A-D by Pedro Henrique Nobre; E-G by Nádia Silvia Somavilla. 
glandular trichomes, abaxial surface densely covered by sessile glandular trichomes; calyx 1-2 mm long, tubular, 2-lobed, apex 4-toothed, externally hirsute, ciliate, with abundant glandular sessile trichomes; corolla tube 6-8 mm long, limb 2-labiate, lilac, hypocrateriform, externally pubescent, with abundant glandular sessile trichomes, throat yellow, pubescent, 4 didynamous stamens, inserted at the middle of the corolla tube, included, thecae parallel; ovary $1 \mathrm{~mm}$ long, ovoid, glabrous, 2-locular, 1 ovule per locule, stigma oblique, lateral. Fruit drupaceous, mesocarp dry, 2-pyrenate, $2 \mathrm{~mm}$ long, spherical, lightbrown, dorsal surface smooth to slightly striated, surrounded by the persistent calyx.

\section{Distribution, habitat and phenology}

Lippia raoniana P.H.Cardoso \& Salimena sp. nov. is known only from two localities in the Diamantina Plateau (Felício dos Santos and Serro), on the Espinhaço Range, Minas Gerais, Brazil, where it seems to be endemic (Fig. 2). The populations are quite small and grow on quartzitic rock outcrops (campos rupestres), at an elevation of 1200-1400 m. Plants were collected with flowers and fruits in January, June, and November.

\section{Prelimiminary conservation status}

Lippia raoniana P.H.Cardoso \& Salimena sp. nov. is only known from two localities, presenting an estimated Area of Occupation (AOO) smaller than $10 \mathrm{~km}^{2}$. The first known population is small and located in the municipality of Serro, along an unpaved road, near to a residential area under urban pressure. The other population is recorded from the municipality of Felício dos Santos, inside a conservation unit. The Diamantina Plateau is now witnessing increasing, uncontrolled tourism, exposing the vulnerability of

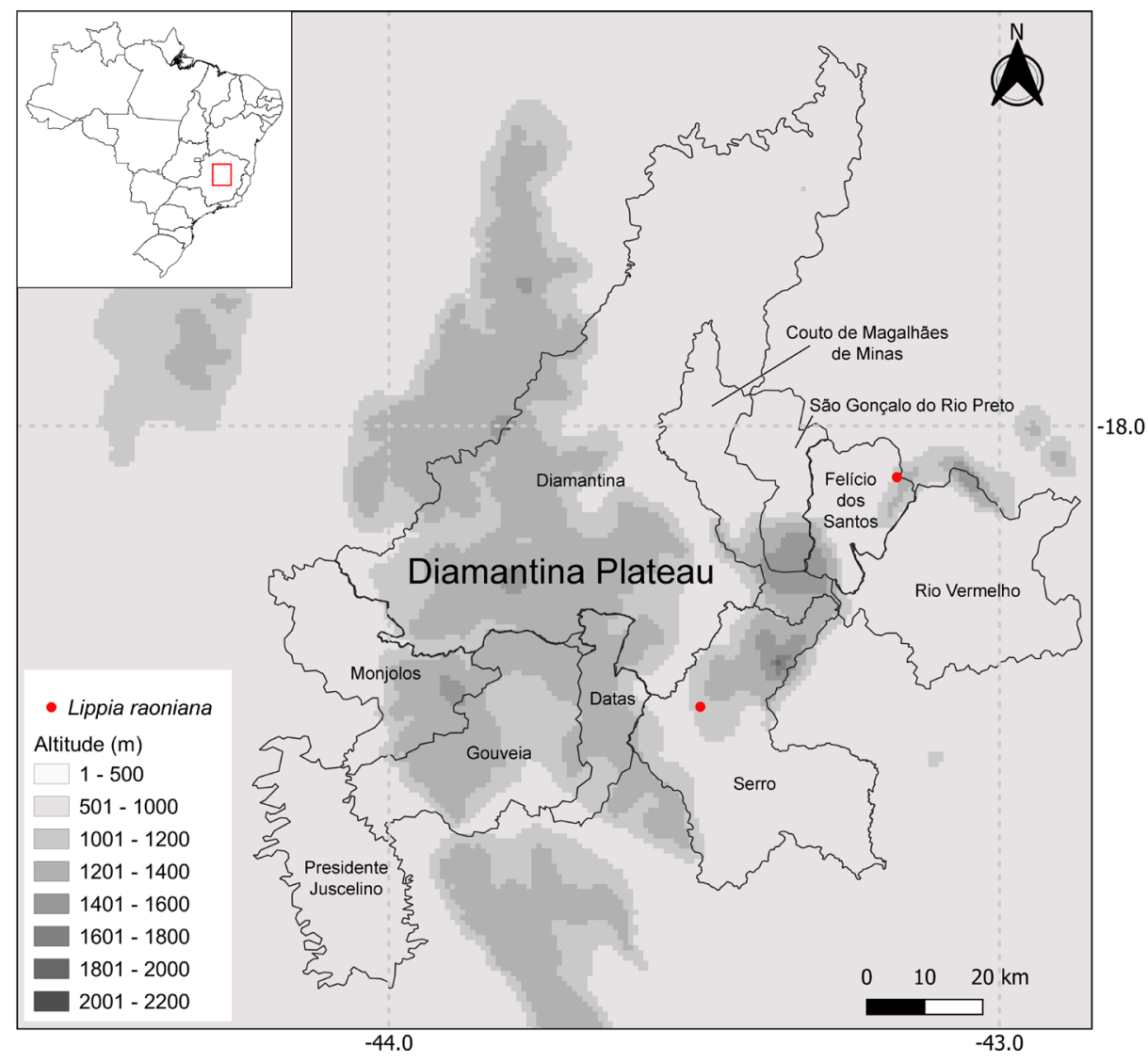

Fig. 2. Map of the Diamantina Plateau, Minas Gerais, Brazil, showing the known distribution of Lippia raoniana P.H.Cardoso \& Salimena sp. nov. 
its soils and vegetation (Schaefer et al. 2002). Thus, L. raoniana sp. nov. may be considered Critically Endangered (CR) based on criteria and sub-criteria B2ab(ii, iii, iv) of IUCN (2019), due to its restricted $\mathrm{AOO}$, number of known locations, and the continuous decline in the quality of its habitat.

\section{Notes}

Lippia raoniana P.H.Cardoso \& Salimena sp. nov. most closely resembles L. spiraeastrum, which is also endemic to the Espinhaço Range, occurring in Grão Mogol, Minas Gerais State (Salimena \& Cardoso 2020), due to the shrubby habit, conspicuous nodes, leaves concentrated in the upper portion of the stem, adaxial surface glandular, axillary inflorescences, capituliform, hemispherical, corolla lilac, and fruit with dry mesocarp, 2-pyrenate. However, several characters of the leaves, peduncles and bracts can be used to distinguish them. The new species is mainly characterized by the combination of ovate leaves with adaxial and abaxial surfaces densely covered by sessile glandular trichomes, peduncles $0.8-1.3 \mathrm{~cm}$ long, and ovate bracts with adaxial and abaxial surfaces densely covered by sessile glandular trichomes.

\section{Identification key to the species of Lippia L. from the Diamantina Plateau, Minas Gerais, Brazil}

1. Inflorescences more than 2 per leaf axil; bracts tetrastichous, the basal ones connate .................... 2

- Inflorescence 1 per leaf axil; bracts spiraled, all free ................................................................... 3

2. Plants with frondose-bracteaose inflorescences ............................................... stachyoides Cham.

- Plants with frondose inflorescences ................................................................. origanoides Kunth

3. Calyx laterally flattened, 2-winged. ......................... L. rubella (Moldenke) T.R.S.Silva \& Salimena

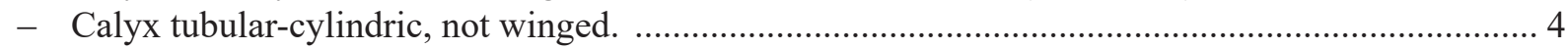

4. Leaves with hyphodromous venation; corolla yellow ............................. L. filifolia Mart. \& Schauer

- Leaves with pinnate venation; corolla pink, lilac, rarely white ...................................................... 5

5. Bracts membranous, pink to magenta, rarely green at base and vinaceous at apex, longer than the corolla tube

- Bracts foliaceous, green, rarely vinaceous at apex, shorter than the corolla tube ......................... 10

6. Leaf-blades abaxially densely pubescent with pedunculate glandular trichomes; bracts green at base, vinaceous at apex L. pseudothea (A.St.-Hil.) Schauer

- Leaf-blades abaxially lacking pedunculate glandular trichomes; bracts pink to magenta 7

7. Leaves ovate-deltoid to suborbicular, margin dentate-lobate ........... L. hederifolia Mart. \& Schauer

- Leaves ovate, broadly ovate or elliptic, margin crenate 8

8. Branches densely velutinous, pedunculate glandular trichomes present; leaves ovate-elliptic to oblong-elliptic

L. rhodocnemis Mart. \& Schauer

- Branches hirsute or pubescent, pedunculate glandular trichomes absent; leaves ovate to broadly ovate

9. Branches and peduncles pubescent; inflorescences hemispheric or cylindric

L. diamantinensis Glaz. ex Moldenke

- Branches and peduncles hirsute; inflorescences globose L. lupulina Cham.

10. Corymbs axillary, densely congested at the apex of the branches ...............................................11

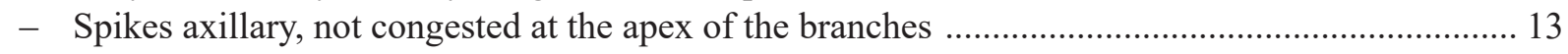


11. Leaf-blades abaxially hirsute, adaxially bullate; bracts elliptic, apex reflexed

L. corymbosa Cham.

- Leaf-blades abaxially tomentose, adaxially slightly bullate; bracts ovate-lanceolate, apex straight .

12. Leaves ovate, base cordate

L. lacunosa Mart. \& Schauer

- Leaves ovate-orbicular or orbicular, base obtuse to cuneate L. rotundifolia Cham.

13. Leaves congested at the apex of the branch, with few tector trichomes; drupe with 2 pyrenes

.L. raoniana P.H.Cardoso \& Salimena sp. nov.

- Leaves evenly distributed along the branch, with several tector trichomes; schizocarp with 2 cluses

14. Leaves obovate to suborbicular; inflorescences few-flowered

L. hermannioides Cham.

- Leaves ovate to ovate-elliptic; inflorescences many-flowered 15

15. Branches sulcate, nodes conspicuous; bracts elliptic L. subracemosa Mansf.

- Branches not sulcate, nodes inconspicuous; bracts ovate or lanceolate 16

16. Branches villous-sericeous; leaves ovate-deltate, abaxially villous-sericeous; bracts lanceolate L. krenakiana P.H.Cardoso, V.I.R.Valério \& Salimena

- Branches strigose; leaves elliptic to ovate-elliptic, adaxially strigose; bracts broadly ovate

L. rosella Moldenke

\section{Discussion}

Our floristic knowledge of Lippia in the State of Minas Gerais has gradually increased in recent years thanks to studies focusing on the Verbenaceae of small areas in the state (e.g., Salimena-Pires \& Giulietti 1998; Salimena \& Silva 2009; Cruz \& Salimena 2017; Cardoso et al. 2018, 2019a, 2019d, 2020a; Santiago et al. 2020). These studies have revealed new distribution records (Cardoso et al. 2019a), and in some cases, new species (Cardoso et al. 2019c, 2020b). It is not surprising that the Diamantina Plateau harbors some yet undescribed species of Lippia, since the region is ultimately considered one of the main diversity and endemism centres in the Espinhaço Range (Giulietti et al. 1997; Echternacht et al. 2011). The recent discovery of Lippia raoniana P.H.Cardoso \& Salimena sp. nov. and L. krenakiana P.H.Cardoso, V.I.R.Valério \& Salimena in the Diamantina Plateau (Cardoso et al. 2020b) added to the understanding of ongoing threats to which the flora of the Espinhaço Range is subjected (Martinelli \& Moraes 2013; Martinelli et al. 2014), emphasizing the need of further taxonomic studies in Lippia. Thus, we present an annotated checklist of the species of Lippia from the area (Table 1). It is important to emphasize that all are found in campos rupestres. In addition, we also provide photographs and an identification key for the 17 species currently recognized in the region (Figs 3-4). This study improves our understanding of species diversity and distributions, and will aid the proposal of new conservation measures for the Espinhaço Range. 

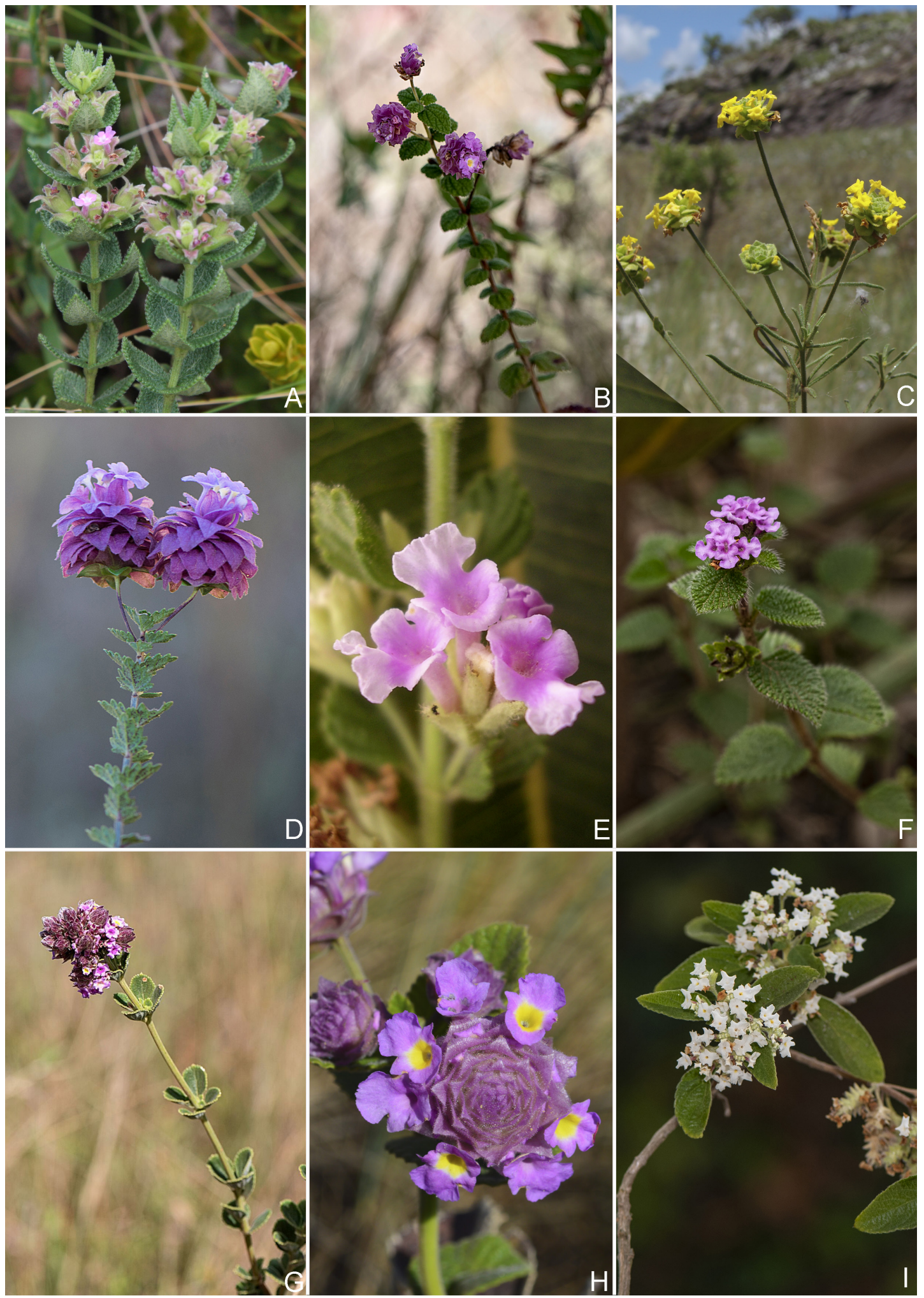

Fig. 3. A. Lippia corymbosa Cham. B. L. diamantinensis Glaz. ex Moldenke. C. L. filifolia Mart. \& Schauer. D. L. hederifolia Mart. \& Schauer. E. L. hermannioides Cham. F. L. krenakiana P.H.Cardoso, V.I.R.Valério \& Salimena. G. L. lacunosa Mart. \& Schauer. H. L. lupulina Cham. I. L. origanoides Kunth. Photos: A by Daniela Zappi; B, D, F-G, I by Pedro Henrique Nobre; C, E by Luiz Menini Neto; $\mathrm{H}$ by Vinicius Dittrich. 

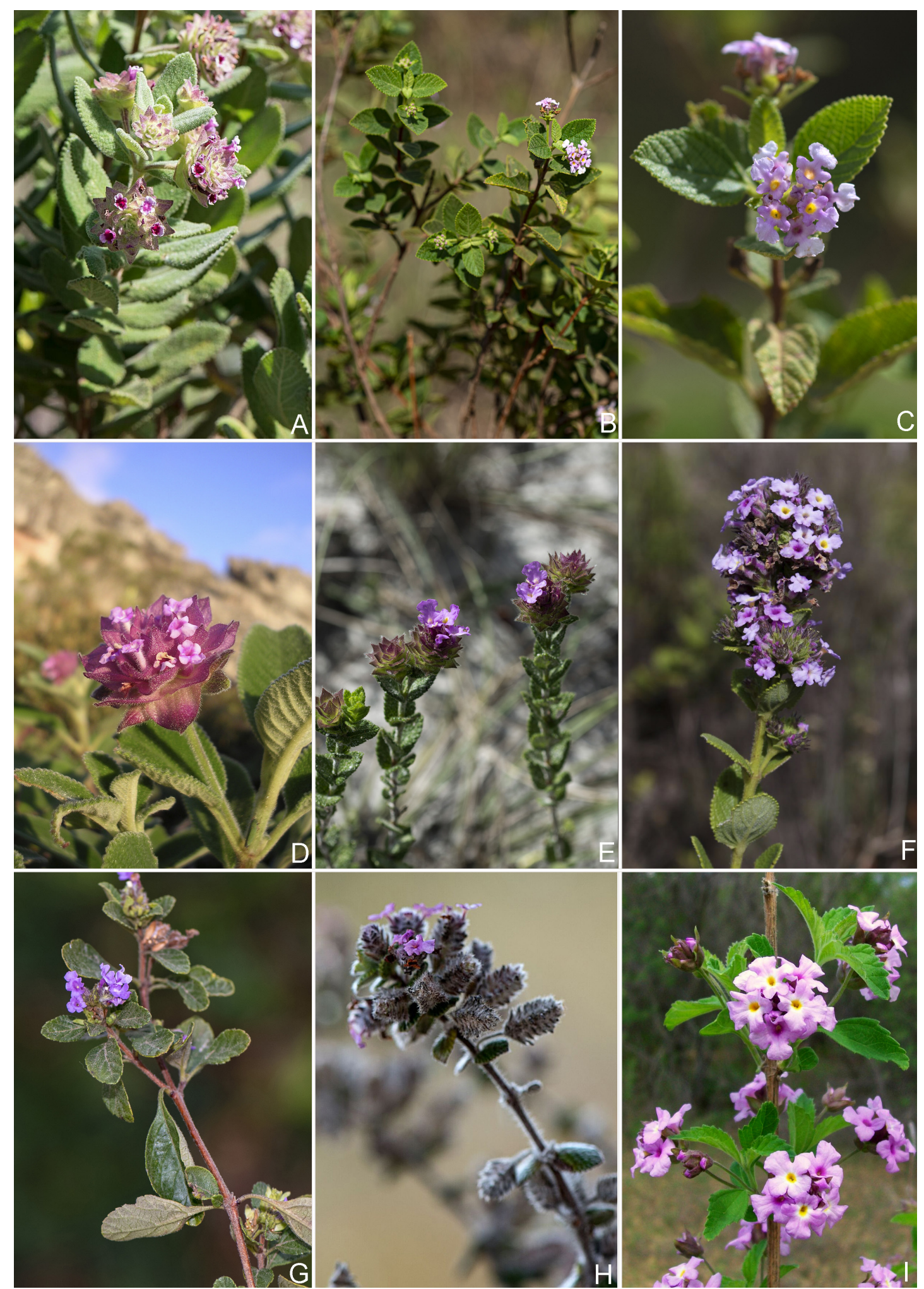

Fig. 4. A. Lippia pseudothea (A.St.-Hil.) Schauer. B-C. L. raoniana P.H.Cardoso \& Salimena sp. nov. D. L. rhodocnemis Mart. \& Schauer. E. L. rosella Moldenke. F. L. rotundifolia Cham. G. L. rubella (Moldenke) T.R.S.Silva \& Salimena. H. L. stachyoides Cham. I. L. subracemosa Mansf. Photos: A-C, E, G-H by Pedro Henrique Nobre; D by Luiz Menini Neto; F by Maurício Mercadante; I by Lucas Marinho. 
Table 1 (continued on the next page). List of species of Lippia L. from the Diamantina Plateau. ${ }^{\dagger}=$ endemic to Minas Gerais State (BFG 2018); ${ }^{*}=$ Endemic to the Diamantina Plateau.

\begin{tabular}{lcc}
\hline $\begin{array}{l}\text { Taxon; } \\
\text { collection number (herbarium) }\end{array}$ & $\begin{array}{c}\text { Distinguishing morphological } \\
\text { characters }\end{array}$ & $\begin{array}{c}\text { Distribution in the } \\
\text { Diamantina Plateau and } \\
\text { official conservation status } \\
\text { (if available) }\end{array}$
\end{tabular}

Lippia corymbosa Cham.;

W.R. Anderson 8843 (NY)

Lippia diamantinensis Glaz. ex

Moldenke ${ }^{\dagger}$;

T.B. Cavalcanti 2294 (CEN)

Lippia filifolia Mart. \& Schauer; J.R. Pirani 5279 (SPF)

Lippia hederifolia Mart. \&

Schauer;

Hatschbach et al. 64657 (MBM)

Lippia hermannioides Cham.;

I. Cordeiro CFCR 9395 (SPF)

Lippia krenakiana P.H.Cardoso, V.I.R.Valério \& Salimena ${ }^{\dagger, *}$; J.R. Pirani 5673 (SPF)

Lippia lacunosa Mart. \& Schauer;

P.T. Sano 1015 (SPF)

Lippia lupulina Cham.;

J.R. Pirani 6309 (SPF)

Lippia origanoides Kunth;

V.C. Souza CFCT 8783 (SPF)

Lippia pseudothea (A.St.-Hil.)

Schauer ${ }^{\dagger}$;

V.C. Souza 20998 (HUEFS)
Branches and leaves hirsute, leaves ternate, subsessile, ovate, margin revolute, adaxially bullate, inflorescences corymbose, short-pedunculate, corolla pink

Branches pubescent, leaves patent, ovate to orbicular, apex round,

base truncate to cordate, inflorescences

hemispheric to cylindric, bracts membranous, pink, corolla pink

Branches viscous, leaves sessile, filiform, margin entire, hyphodromous venation, corolla yellow

Leaves subsessile, congested at the apex of the branches, ovate-deltoid to suborbicular, margin dentate-lobate, adaxially nitid, bracts and corolla pink to magenta

Leaves obovate to suborbicular, margin entire up to mid-length, crenate-dentate at apex, adaxially scabrid, bullate, inflorescences fewflowered, corolla white turning pink

Leaves ovate-deltoid, sericeous-lanate with dense sessile and pedunculate glandular trichomes, inflorescences short-pedunculate, bracts lanceolate, corolla pink

Leaves patent, subsessile, coriaceous, ovate, abaxially foveolate, inflorescences corymbose-paniculate, at the apex of the branches, bracts sericeous, corolla pink or lilac

Branches and peduncles hirsute, leaves ovate to orbicular, apex obtuse, base obtuse to cordate, inflorescences globose, bracts membranous, pink, corolla pink

Leaves opposite, inflorescence frondose, many per leaf axil, bracts tetrastichous, imbricate, the basal ones connate, the apical ones free, corolla white

Leaves sessile, spathulate, adaxially with dense pedunculate glandular trichomes, bracts membranous, greenish-pink with vinaceous apex, corolla pink
Diamantina, Gouveia,

Presidente Juscelino

Couto de Magalhães de Minas, Diamantina, Gouveia

Diamantina, Presidente Juscelino

Diamantina, Felício dos

Santos, São Gonçalo do Rio Preto, Serro

Diamantina, Felício dos

Santos, Gouveia, Rio

Vermelho, São Gonçalo do Rio Preto, Serro

Diamantina

Datas, Diamantina, Gouveia, São Gonçalo do Rio Preto, Serro

Couto de Magalhães de Minas, Diamantina, Gouveia, Presidente Juscelino, Serro

Couto de Magalhães de Minas, Diamantina, Gouveia, Monjolos, Serro

Datas, Diamantina, Felício dos Santos, Gouveia,

Presidente Juscelino, São Gonçalo do Rio Preto, Serro 
Table 1 (continued). List of species of Lippia L. from the Diamantina Plateau. ${ }^{\dagger}=$ endemic to Minas Gerais State (BFG 2018); ${ }^{*}=$ Endemic to the Diamantina Plateau.

\begin{tabular}{|c|c|c|}
\hline $\begin{array}{l}\text { Taxon; } \\
\text { collection number (herbarium) }\end{array}$ & $\begin{array}{c}\text { Distinguishing morphological } \\
\text { characters }\end{array}$ & $\begin{array}{c}\text { Distribution in the } \\
\text { Diamantina Plateau and } \\
\text { official conservation status } \\
\text { (if available) }\end{array}$ \\
\hline $\begin{array}{l}\text { Lippia raoniana P.H.Cardoso \& } \\
\text { Salimena sp. nov.,"*; } \\
\text { Salimena et al. } 1382 \text { (CESJ) }\end{array}$ & $\begin{array}{c}\text { Leaves congested at the apex of the branches, } \\
\text { ovate, densely covered by sessile glandular } \\
\text { trichomes, bracts ovate, corolla lilac, } \\
\text { drupe with } 2 \text { pyrenes }\end{array}$ & Felício dos Santos, Serro \\
\hline $\begin{array}{l}\text { Lippia rhodocnemis Mart. \& } \\
\text { Schauer }{ }^{\dagger, *} \text {; } \\
\text { N.L. Menezes CFCR } 7703 \text { (SPF) }\end{array}$ & $\begin{array}{l}\text { Branches velutine, leaves petiolate, } \\
\text { ovate-elliptic to oblong-elliptic, } \\
\text { adaxially velutine, bracts membranous, } \\
\text { pink to magenta, corolla pink }\end{array}$ & $\begin{array}{c}\text { Felício dos Santos, Rio } \\
\text { Vermelho, São Gonçalo do } \\
\text { Rio Preto, Serro } \\
\text { EN B1ab(i, iii, iv) (Salimena } \\
\text { et al. 2013) }\end{array}$ \\
\hline $\begin{array}{l}\text { Lippia rosella Moldenke }{ }^{\dagger, *} \text {; } \\
\text { J.R. Pirani CFCR } 8707 \text { (NY) }\end{array}$ & $\begin{array}{l}\text { Branches strigose, leaves opposite or ternate, } \\
\text { adaxially scabrid, abaxially glandular- } \\
\text { strigose, bracts broadly ovate, green, } \\
\text { vinaceous at apex, corolla pink }\end{array}$ & Diamantina \\
\hline $\begin{array}{l}\text { Lippia rotundifolia Cham.; } \\
\text { N. Roque } 226 \text { (SPF) }\end{array}$ & $\begin{array}{l}\text { Branches tomentose-velutine, leaves } \\
\text { ovate-orbicular to orbicular, coriaceous, } \\
\text { base obtuse to cuneate, inflorescences } \\
\text { consisting of many-flowered corymbs, } \\
\text { bracts hirsute, corolla lilac or magenta }\end{array}$ & $\begin{array}{l}\text { Datas, Diamantina, Gouveia, } \\
\text { Rio Vermelho, São Gonçalo } \\
\text { do Rio Preto, Serro }\end{array}$ \\
\hline $\begin{array}{l}\text { Lippia rubella (Moldenke) } \\
\text { T.R.S.Silva \& Salimena }{ }^{+, *} ; \\
\text { F.R.G. Salimena } 3684 \text { (CESJ) }\end{array}$ & $\begin{array}{l}\text { Leaves elliptic, margin entire up to } \\
\text { mid-length, serrate towards the apex, } \\
\text { inflorescences lax, calyx laterally } \\
\text { compressed, 2-winged, corolla pink }\end{array}$ & $\begin{array}{c}\text { Diamantina } \\
\text { EN B2ab(i, ii, iii) (Salimena } \\
\text { et al. 2014) }\end{array}$ \\
\hline $\begin{array}{l}\text { Lippia stachyoides Cham.; } \\
\text { P.T. Sano } 754 \text { (SPF) }\end{array}$ & $\begin{array}{l}\text { Leaves opposite, inflorescences } \\
\text { frondose-bracteose, many per leaf axil, } \\
\text { bracts tetrastichous, imbricate, } \\
\text { corolla white or magenta }\end{array}$ & $\begin{array}{c}\text { Datas, Diamantina, Gouveia, } \\
\text { Rio Vermelho, São Gonçalo } \\
\text { do Rio Preto }\end{array}$ \\
\hline $\begin{array}{l}\text { Lippia subracemosa Mansf.; } \\
\text { J.R. Pirani } 4416 \text { (SPF) }\end{array}$ & $\begin{array}{l}\text { Internodes long, nodes conspicuous, } \\
\text { inflorescences capituliform, long- } \\
\text { pedunculate, bracts elliptic, congested, } \\
\text { apex acute to obtuse, corolla pink }\end{array}$ & Monjolos \\
\hline
\end{tabular}




\section{Acknowledgments}

We thank Prof. Dr Pedro Henrique Nobre for facilitating the expedition to collect Lippia raoniana sp. nov. and Dr Nádia Silvia Somavilla for sectioning the fruits. We also thank Daniela Zappi, Lucas Marinho, Maurício Mercadante, Pedro Henrique Nobre and Vinicius Dittrich for the photos of the species. The first author also thanks CNPq, Conselho Nacional de Desenvolvimento Científico e Tecnológico - Brasil, for the doctoral grant (process 141837/2020-9). Marcelo Trovó thanks the Alexander von Humboldt Foundation (BRA/1139098), FAPERJ (E26/203.269/2016 and E-26/202.708/2019—JCNE), and CNPq (470349/2013-1-Universal, 306758/2019-9-Pq2) for financial support. The last author thanks the CNPq (REFLORA/563560/2010-0) for the financial support to review the Verbenaceae types in Europe.

\section{References}

Almeida-Abreu P.A. 1995. O supergrupo Espinhaço da Serra do Espinhaço Meridional (Minas Gerais): o rifte, a bacia e o orógeno. Geonomos 3: 1-18. https://doi.org/10.18285/geonomos.v3i1.211

Atkins S. 2004. Verbenaceae. In: Kubitzki K. \& Kadereit J.W. (eds) The Families and Genera of Vascular Plants: 449-468. Springer-Verlag, Berlin. https://doi.org/10.1007/978-3-642-18617-2_25

Cardoso P.H., Cabral A., Valério V.I.R. \& Salimena F.R.G. 2018. Verbenaceae na Serra Negra, Minas Gerais, Brasil. Rodriguésia 69: 777-786. https://doi.org/10.1590/2175-7860201869235

Cardoso P.H., Cabral A., Santos-Silva F. \& Salimena F.R.G. 2019a. Verbenaceae no Parque Estadual da Serra do Papagaio, Minas Gerais, Brasil. Rodriguésia 70: e02932017.

https://doi.org/10.1590/2175-7860201970056

Cardoso P.H., Menini Neto L. \& Salimena F.R.G. 2019b. A new species of Lippia (Verbenaceae) from the inselbergs of Brazilian Atlantic Forest. Phyotaxa 406: 243-249.

https://doi.org/10.11646/phytotaxa.406.4.3

Cardoso P.H., Menini Neto L. \& Salimena F.R.G. 2019c. Lippia mantiqueirae (Verbenaceae), a new species from Minas Gerais, Brazil. Phytotaxa 420: 249-254. https://doi.org/10.11646/phytotaxa.420.3.5

Cardoso P.H., Santos-Silva F., Menini Neto L. \& Salimena F.R.G. 2019d. Verbenaceae no Parque Nacional do Caparaó, Serra da Mantiqueira, Brasil. Hoehnea 46: e652019.

https://doi.org/10.1590/2236-8906-65/2019

Cardoso P.H., Cabral A., Santos-Silva F. \& Salimena F.R.G. 2020a. Verbenaceae no Parque Nacional da Serra da Canastra, Minas Gerais, Brasil. Rodriguésia 71: e03072018.

https://doi.org/10.1590/2175-7860202071032

Cardoso P.H., Valério V.I.R., Menini Neto L., Trovó M. \& Salimena F.R.G. 2020b. Novelties in Lippia (Verbenaceae) from Minas Gerais State, Brazil. Phytotaxa 455: 47-52.

https://doi.org/10.11646/phytotaxa.455.1.6

Chamisso L.K.A. 1832. Verbenaceae. Linnaea 7: 105-723.

Cruz L.V.V. \& Salimena F.R.G. 2017. Verbenaceae J.St.-Hil. do Parque Estadual do Ibitipoca, Minas Gerais, Brasil. Boletim de Botânica da Universidade de São Paulo 35: 65-74. https://doi.org/10.11606/issn.2316-9052.v35i0p65-74

Echternacht L., Trovó M., Oliveira C.T. \& Pirani J.R. 2011. Areas of endemism in the Espinhaço Range in Minas Gerais, Brazil. Flora - Morphology, Distribution, Functional Ecology of Plants 206: 782-791. https://doi.org/10.1016/j.flora.2011.04.003

Giulietti A.M., Pirani J.R. \& Harley R. 1997. Espinhaço Range region, eastern Brazil. In: Davis S.D., Heywood V.H., Herrera-MacBryde O., Villa-Lobos J. \&. Hamilton A.C. (eds) Centres of Plant Diversity: 397-404. IUCN publications, Cambrige. 
Gonçalves D.J.P., Shimizu G.H., Yamamoto K. \& Semir J. 2017. Vochysiaceae na região do Planalto de Diamantina, Minas Gerais, Brasil. Rodriguésia 68: 159-193.

https://doi.org/10.1590/2175-7860201768124

Gonçalves E.G. \& Lorenzi H. 2007. Morfologia vegetal: Organografia e Dicionário ilustrado de Morfologia das Plantas vasculares. Instituto Plantarum, Nova Odessa.

Gontijo B.M. 2008. Uma geografia para a Cadeia do Espinhaço. Megadiversidade 4: 7- 14.

Harris J.G. \& Harris M.W. 2003. Plant Identification Terminology: an Illustrated Glossary. $2^{\text {nd }}$ Edition. Spring Lake Publ., Spring Lake.

IUCN Standards and Petitions Committee. 2019. Guidelines for Using the IUCN Red List Categories and Criteria. Version 14. Available from http://www.iucnredlist.org/documents/RedListGuidelines.pdf [accessed 30 Jun. 2020].

King L. 1956. Geomorfologia do Brasil Oriental. Revista Brasileira de Geografia 18: 1-147.

Lu-Irving P. \& Olmstead R.G. 2013. Investigating the evolution of Lantaneae (Verbenaceae) using multiple loci. Botanical Journal of the Linnean Society 171: 103-119.

https://doi.org/10.1111/j.1095-8339.2012.01305.x

Martinelli G. \& Moraes M.A. 2013. Livro vermelho da Flora do Brasil. Instituto de Pesquisas Jardim Botânico do Rio de Janeiro, Rio de Janeiro.

Martinelli G., Messina T. \& Santos Filho L. 2014. Livro vermelho da Flora do Brasil - Plantas raras do Cerrado. Instituto de Pesquisas Jardim Botânico do Rio de Janeiro, Rio de Janeiro.

Marx H.E., O’Leary N., Yuan Y.-W., Lu-Irving P., Tank D.C., Múlgura M.E. \& Olmstead R.G. 2010. A molecular phylogeny and classification of Verbenaceae. American Journal of Botany 97: 1647-1663.

https://doi.org/10.3732/ajb.1000144

Myers N., Mittermeier R.A., Mittermeier C.G., Fonseca G.A.B. \& Kent J. 2000. Biodiversity hotspots for conservation priorities. Nature 403: 853-858. https://doi.org/10.1038/35002501

QGIS Development Team. 2018. QGIS Geographic Information System. ver. 3.8. Open Source Geospatial Foundation Project. Available from https://www.qgis.org [accessed 14 May 2020].

Radford A.E., Dickinson W.C., Massey J.R. \& Bell C.R. 1974. Vascular Plant Systematics. Harper Collins, New York.

Rapini A., Mello-Silva R. \& Kawasaki M.L. 2002. Richness and endemism in Asclepiadoideae (Apocynaceae) from the Espinhaço Range of Minas Gerais, Brazil - a conservationist view. Biodiversity \& Conservation 11: 1733-1746. https://doi.org/10.1023/A:1020346616185

Saadi A. 1995. A geomorfologia da Serra do Espinhaço em Minas Gerais e de suas Margens. Geonomos 3: 41-63. https://doi.org/10.18285/geonomos.v3i1.215

Salimena-Pires F.R.G. \& Giulietti A.M. 1998. Flora da Serra do Cipó, Minas Gerais: Verbenaceae. Boletim de Botânica da Universidade de São Paulo 17: 155-186.

https://doi.org/10.11606/issn.2316-9052.v17i0p155-186

Salimena F.R.G. \& Cardoso P.H. 2020. Lippia in Flora do Brasil 2020 under construction. Jardim Botânico do Rio de Janeiro.

Available from http://floradobrasil.jbrj.gov.br/reflora/floradobrasil/FB15170 [accessed 25 Jan. 2021].

Salimena F.R.G. \& Silva T.R.S. 2009. Flora de Grão-Mogol, Minas Gerais: Verbenaceae. Boletim de Botânica da Universidade de São Paulo 27: 119-126.

https://doi.org/10.11606/issn.2316-9052.v27ilp119-120 
Salimena F.R.G., França F. \& Silva T.R.S. 2009. Verbenaceae. In: Giulietti A.M., Rapini A., Andrade M.J.G., Queiroz L.P. \& Silva J.M.C. (eds) Plantas raras do Brasil: 399-405. Conservação Internacional, Belo Horizonte.

Salimena F.R.G., Kutschenko D.C., Monteiro N.P. \& Mynssen C. 2013 Verbenaceae. In: Martinelli G. \& Moraes M.A. (eds) Livro vermelho da Flora do Brasil: 1010-1016. Instituto de Pesquisas Jardim Botânico do Rio de Janeiro, Rio de Janeiro.

Salimena F.R.G., Moraes L., Kutschenko D.C. \& Novaes L. 2014. Verbenaceae. In: Martinelli G., Messina T. \& Santos-Filho L. (eds) Livro vermelho da Flora do Brasil - Plantas raras do Cerrado: 266-273. Instituto de Pesquisas Jardim Botânico do Rio de Janeiro, Rio de Janeiro.

Sanders R.W. 2001. The genera of Verbenaceae in the southeastern United States. Harvard Papers in Botany 5: 303-358.

Santiago A.O., Cardoso P.H., Salimena F.R.G. \& Trovó M. 2020. Verbenaceae no Parque Nacional do Itatiaia, Brasil. Rodriguésia 71: e02462018. https://doi.org/10.1590/2175-7860202071066

Schaefer C.E.R., Ker J.C., Gilkes R.J. Campos J.C., Costa L.M. \& Saadi A. 2002. Pedogenesis on the uplands of the Diamantina Plateau, Minas Gerais, Brazil: a chemical and micropedological study. Geoderma 107: 243-269. https://doi.org/10.1016/S0016-7061(01)00151-3

Schauer J.C. 1847. Verbenaceae. In: Candolle A.P. de (ed.) Prodromus Systematis naturalis Regni vegetabilis 11: 522-700. Treuttel et Würtz, Paris.

Silva T.R.S. 1999. Redelimitação e revisão do gênero Lantana L. (Verbenaceae) no Brasil. $\mathrm{PhD}$ thesis, Universidade de São Paulo, São Paulo.

Silva T.R.S. \& Salimena F.R.G. 2002. Novas combinações e novos sinônimos em Lippia e Lantana (Verbenaceae). Darwiniana 40: 57-59.

Thiers B. continuously updated. Index Herbariorum: A Global Directory of Public Herbaria and Associated Staff. New York Botanical Garden's Virtual Herbarium.

Available from http://sweetgum.nybg.org/science/ih/ [accessed 5 Jun. 2020].

Troncoso N.S. 1974. Los géneros de verbenáceas de Sudamérica extratropical. Darwiniana 18: 295-412.

UNESCO - United Nations Educational, Scientific and Cultural Organization. 2005. Espinhaço Range Biosphere Reserve, Brazil. Available from: https://en.unesco.org/biosphere/lac/espinhaco [accessed 30 Jun. 2020].

Manuscript received: 29 August 2020

Manuscript accepted: 10 November 2020

Published on: 28 January 2021

Topic editor: Frederik Leliaert

Desk editor: Radka Rosenbaumová

Printed versions of all papers are also deposited in the libraries of the institutes that are members of the EJT consortium: Muséum national d'histoire naturelle, Paris, France; Meise Botanic Garden, Belgium; Royal Museum for Central Africa, Tervuren, Belgium; Royal Belgian Institute of Natural Sciences, Brussels, Belgium; Natural History Museum of Denmark, Copenhagen, Denmark; Naturalis Biodiversity Center, Leiden, the Netherlands; Museo Nacional de Ciencias Naturales-CSIC, Madrid, Spain; Real Jardín Botánico de Madrid CSIC, Spain; Zoological Research Museum Alexander Koenig, Bonn, Germany; National Museum, Prague, Czech Republic. 